\title{
URGENSI BELAJAR BAHASA ARAB
}

\author{
Muhlis Muhammad Abdullah \\ Sekolah Tinggi Agama Islam Negeri (STAIN) Sorong, Papua Barat, Indonesia \\ Jurusan Dakwah Program Studi Komunikasi Penyiaran Islam \\ muhlismuhammadabdullah@gmail.com
}

\begin{abstract}
ABSTRAK
Urgensi suatu bahasa dapat dilihat dari fungsinya yang mempunyai peran penting bagi kehidupan manusia. Ada tiga fungsi, yaitu ideational, interpersonal, social, dan textual. Dari fungsi ini, kehidupan manusia tidak dapat dilepaskan dari bahasa. Bahasa dan manusia bagaikan dua sisi mata uang yang apabila hilang salah satunya, maka kehidupan ini tidak banyak memberi makna bagi dirinya dan orang lain. Oleh sebab itu, penciptaan manusia seiring dengan penciptaan kemampuan berbahasanya, dan hanya manusialah yang memiliki bahasa yang sebenarnya.
\end{abstract}

\section{PENDAHULUAN}

Betapa urgensiya bahasa bagi kita. Tanpa bahasa kita tidak dapat berbudaya, tidak dapat berkreasi, dan tidak mempunyai peradaban maju. Hal ini dapat dilihat pada makhlukmakhluk lain, seperti binatang, tumbuh-tumbuhan,planet, dsb. Kehidu-pan mereka statis sejak diciptakannya sampai kini.

Di sini akan terlihat bahwa bahasa memberi pengaruh yang kuat kepada masyarakat, karena urgensinya bukan saja sebagai media komunikasi, tetapi juga menjadi modal hajat hidup manusia. Kita tidak berhenti belajar bahasa selama masih ada manusia di muka bumi ini.

Fungsi-fungsi bahasa Arab bagi pelajar/mahasiswa merupakan kebutuhan yang penting, karena ia telah menjadi bahasa agama, bahasa komunikasi resmi antar bangsa (PBB), bahasa dunia Islam, bahasa perdagangan, bahasa ekonomi dan perbangkan Islam, bahasa kebudayaan, bahasa ilmu pengetahuan dan teknologi, bahasa hukum, bahasa gaul, dsb. Hal ini menarik para ahli untuk memperbincangkan dan melakukan studi sebagaimana layaknya bahasa-bahasa yang terkenal lainnya, seperti bahasa Inggris, Mandarin, dsb. Oleh sebab itu, sejak dahulu sampai kini, hampir tidak ada negara dan perguruan tinggi di dunia ini, di negara-negara maju, yang tidak membuka jurusan atau program studi bahasa Arab atau kajian-kajian yang bernuansa bahasa dan peradaban Arab. 


\section{FUNGSI TEKSTUAL BAHASA ARAB}

Hubungan bahasa Arab dengan Al-qur`an dan Hadis Nabi SAW sebagai sumber utama agama Islam tidak bisa dipisahkan. Al-qur`an diturunkan dengan bahasa Arab dan tidak pernah ada Al-Qur`an dengan bahasa lainnya. Oleh sebab itu, hampir dapat dikatakan bahwa seseorang akan mengalami kesulitan dalam memahami Al-Qur`an secara mendalam tanpa menguasai bahasa Arab yang menjadi bahasa Al-Qur`an. Banyak penelitian yang mengatakan bahwa ada hubungan yang kuat antara pemahaman bahasa Arab dengan pemahaman mata kuliah mata kuliah yang menggunakan bahasa Arab, seperti tafsir, hadist, dsb. Seseorang tidak akan menjadi ulama atau ustadz yang profesional jika tidak menguasai bahasa Arab. Kajian tentang kata "iman dan kufur" dalam Al-Quran, misalnya, menimbulkan pengaruh yang hebat di kalangan ulama dan kaum muslimin, sehingga melahirkan persoalan politik dan menimbulkan banyak paham, seperti Jabariyah, Qadariyah, Murji'ah, dsb, serta aliran teologi Islam, seperti Mu'tazilah, Ahlu Sunnah Wal Jama'ah, dsb(Harun Nasution, 1986).

Terjadinya perbedaan pendapat di kalangan para mujtahid, (pakar dalam kajian Islam) sangat dipengaruhi oleh bahasa Arab sebagai faktor yang dominan, baik dari segi struktur, semantik, maupun leksikonnya. Hal ini dengan luas dijelaskan oleh Thawilah dalam bukunya "Atsar al-Lughah fi Ikhtilaf al-Mujtahidin dan buku Ikhtilaf al-Mufassrin asbabuh wa atsaruh $(1414 \mathrm{H})$ " yang menggambar-kan tentang pengaruh bahasa Arab terhadap para mujtahid dan para mufassir.

Dalam kalangan ulama tafsir-hadis, perselihan pendapat dan perbedaan paham juga terjadi karena faktor bahasa. Sebagaimana dijelaskan Al-Faisan dalam bukunya "Ikhtif alMufassrin, Asbabuh Wa Atsaruh (1997)”.

Dalam pelajaran fiqih dan ushul fiqih, urgensi bahasa Arab tidak dapat disangkal lagi, karena materi ajarnya berisikan tentang kaidah-kaidah fiqih dan ushul yang notabene adalah kaidah bahasa Arab.Di sini bahasa Arab telah menjadi bahasa hukum Islam (bagian dari syari'ah).

Fungsi tekstual (karya tulis ulama) turut mempengaruhi tingkah laku atau amal perbuatan kaum beragama (Islam dan lainnya) dalam ibadah, pola pikirnya, cara pandangnya, pilihan teologinya, dsb. Coba kita perhatikan tingkah laku kaum muslimin di Ulakan Pariaman, di Demak (Jawa tengah), di Iran, di Afganistan, Turki, dsb. 
Paparan di atas dapat disimpulkan bahwa pelajar/mahasiswa yang tidak menguasai bahasa Arab akan mengalamai kesulitan dalam studinya jika tidak ditunjang oleh bahasa Arab sebagai alat bantu utamanya untuk memahaminya. Dengan demikian, jelaslah bahwa bahasa Arab dalam kajian ilmu-ilmu yang disebutkan di atas adalah sangat urgen.

\section{FUNSI SOSIAL BAHASA ARAB}

Dalam kajian sosiolinguistik, bahasa, setidaknya, berhubungan dengan empat hal:

1. Bahasa mempengaruhi masyarakat,

2. Masyarakat mempengaruhi bahasa,

3. Masyarakat dan bahasa saling berpengaruh, dan

4. Bahasa dan masyarakat tidak saling mempengaruhi.

Berkembangnya secara pesat perekonomian, ilmu pengetahuan, peradaban, dan pergaulan masyarakat tutur Arab menyebabkan bahasa Arab tidak lagi berada pada wilayah Timur tengah saja, tetapi merambah ke penjuru dunia. Masyarakat dunia merasakan betapa pentingnya mempelajari bahasa Arab dan kajian-kajian Timur Tengah. Sejak dahulu sampai kini, bahasa Arab telah dipelajari oleh masyarakat dunia dan hampir tidak ada universitas di negara maju yang tidak membuka jurusan bahasa Arab, misalnya, di Barat, sejak abad XI, sebagian masyarakat Eropa telah mempelajari bahasa Arab, karena buku-buku ilmiah, seperti kedokteran, IPA, matematika,dll yang ada di Toledo, Seviila, dan Cordova, banyak bertulisan bahasa Arab, maka para Raja, misalnya Ferederik II dan Alfonso X, menyuruh semua rakyatnya mempelajari bahasa Arab, karena mampu berbahasa Arab, pada saat itu, merupakan gengsi dan kebanggaan bagi sebagian masyarakat Eropa.

\section{BAHASA ARAB SEBAGAI BAHASA POLITIK}

Dari segi politik, bahasa Arab telah berkembang dan mempengaruhi dunia bagian Timur dan Barat. Di bagian Timur, masyarakat tutur bahasa Arab sangat banyak jumlahnya, mulai dari Marokko, Aljazair, Libia,Republik Persatuan Arab,Sudan, Lebanon,Saudi Arabia, Siria, Yordania, Irak, Iran, Afganistan, Turki, Mesir, sebagian wilayah Afrika Utara, dsb. Negara-negara ini adalah negara yang tingkat perekonomiannya stabil, kaya, dan berperadaban maju. Kebutuhan negara-negara tersebut terhadap tenaga kerja Indonesia hampir tidak terpenuhi, karena faktor kemampuan berbahasa Arab pada anak-anak bangsa ini lemah. Dalam organisasi Dunia, bahasa Arab, sejak tahun 1973, telah 
menjadi bahasa keenam yang resmi dipakai untuk bahasa persidangan PBB dan menjadi bahasa utama yang dipakai berkomunikasi dalam OKI (Organisasi Konferensi Dunia Islam).

\section{BAHASA ARAB SEBAGAI BAHASA EKONOMI ISLAM, PERBANKAN ISLAM, DAN HUKUM ISLAM}

Krisis ekonomi yang melanda dunia akhir-akhir ini membuat perhatian masyarakat ekonomi melirik pengembangan ekonomi dan perbankan dengan sistem syari'ah. yang diharapkan lebih mempunyai daya tahan dari krisis. Bahkan di Indonesia, hampir-hampir tidak ada bank yang tidak membuka bank syari'ah. Hal ini memberi efek kepada perkembangan dan pertumbuhan kosa kata Arab (mufradat) baru yang berhubungan dengan perekonomian dan perbankan. Maka populerlah istilah muamalah, mudharabah, murabahah, baitul mal wa tamwil, qardhul hasan, ujrah, wakalah, hawalah, kafalah, rahn , shada-qah, zakat, infaq, waqaf, tauliyah, isyrak, wadhi'ah, tsaman, nasi'ah, tasharruf, sharf, salam, dsb. Semua kosa kata ini berbahasa Arab yang harus dipahami maksud dan konteks pemakaiannya oleh para pembelajar/mahasiswa agar tidak ketinggalan zaman dan buta makna. Dengan demikian, gengsi bahasa Arab terus berkembang ke arah yang positif dan moderen, karena menjadi bahasa pergau-lan antar masyarakat, kaum terpelajar, dsb.

\section{BAHASA ARAB SEBAGAI BAHASA KEBUDAYAAN}

Peranan bahasa Arab dalam kebudayaan dunia dan nasional telah mengambil bagian penting sejak berkembangnya agama Islam di Nusantara pada abad XIII dan sampai saat ini masih dirasakan peranannya secara leksikal maupun semantik. Hal ini terlihat pada berbagai bidang. Misalnya pada upacara sekaten di Kraton Surakarta dan Yogyakarta, upacara perkawinan, khataman, khitanan, kata sakral atau mantera-mantera yang dipakai oleh masyarakat Indonesia adalah menggu-nakan huruf atau kata-kata bahasa Arab. Bahkan ungkapan-ungkapan tertentu yang banyak dipakai oleh masyarakat Indonesia secara meluas dan merakyat dengan menggunakan bahasa Arab.

Bahasa Arab juga sangat berperan dalam karya-karya tulis anak-anak bangsa Indonesia. Banyak buku yang dikarang oleh ustadz atau ulama di Indonesia dengan menggunakan huruf Arab-Melayu, seperti buku Perukunan, Sifat duapuluh, dan buku-buku yang berkaitan dengan ibadah, hikayat, sejarah Nabi Muhammad, tasawuf, dan sebagainya.

Dalam bidang kesusasteraan Indonesia pada zaman pujangga lama banyak ditulis dengan huruf Arab-Melayu yang banyak menggunakan kata-kata yang berasal dari bahasa 
Arab, maka mempelajari bahasa Arab bagi pelajar Indonesia, terutama jurusan sastra Indonesia, merupakan kunci untuk menggali kesussteraan Indonesia lama, karena banyaknya kata-kata Arab yang digunakan atau yang diambil menjadi kata-kata bahasa Indonesia sekarang.

\section{PEMBELAJARAN BAHASA ARAB}

Pembelajaran bahasa Arab yang efektif memerlukan paradigma baru dalam merancang materi ajar dan pembelajarannya. Materi-materi ajar yang sudah usang, dan tidak sesuai dengan kebutuhan pembelajar hari ini dan ke depan, serta pembelajaran yang tidak komunikatif dan pragmatik akan membuang-buang waktu saja. Namun ini semua juga ada hubungannya dengan minat dan motivasi pembelajarnya dan perhatian lembaga pendidikan dalam memenuhi sarana dan prasana yang mendukung pembelajarannya. Tujuan pembelajaran bahasa Arab yang dibutuhkan hari ini adalah:

a. Membentuk pelajar

1) Terampil mendengar dan berbicara (maharah istima'-kalam) dengan topiktopik yang komunikatif dan kontekstual

2) Terampil membaca dan menulis bahasa Arab (maharah qira'ah-kitabah), yaitu membaca teks topik-topik tentang sosial keagamaan dan keprodian, serta menulis, yaitu melambangkan huruf/ kata-kata bahasa Arab dengan baik dan benar) dalam konteks kebutuhannya hari ini dan ke depan.

Tujuan ini terlihat bahwa fokus pembelajaran bahasa Arab untuk berkomunikasi, yaitu pembentukan keterampilan berbahasa; bukan kepada pengetahuan bahasa. Pengetahuan bahasa bersifat terapan; bukan teoritis.

Pendekatan Pembelajaran sesuai dengan tujuan di atas, pendekatan pembelajaran yang efektif mencakup empat pendekatan, yaitu pendekatan humanistik, komuni-katif, kontekstual, dan struktural.

1) Pendekatan humanistik melihat bahwa pembelajaran bahasa Arab memerlukan keaktifan pembelajarnya, bukan pengajar. Pelajarlah yang aktif belajar bahasa dan pengajar berfungsi sebagai motivator, dinamisator, administrator, evaluator, dsb.

2) Pendekatan komunikatif melihat bahwa fungsi utama bahasa adalah komunikasi. Hal ini berarti materi ajar bahasa Arab harus materi yang praktis dan pragmatis, 
yaitu materi ajar terpakai dan dapat dikomuni-kasikan oleh pelajar secara lisan maupun tulisan.

3) Pendekatan kontekstual melihat bahasa sebagai suatu makna yang sesuai dengan kebutuhan pembelajar dan seting-nya. Di sini, rancangan materi ajar harus berdasarkan kebutuhan lembaga, kebu-tuhan pembelajar hari ini dan ke depan.

4) Pendekatan struktural melihat bahwa pembelajaran bahasa sebagai hal yang formal. Oleh sebab itu, struktur bahasa (qawaid) harus mendapat perhatian dalam merancang materi ajar. Namun struktur harus fungsional agar komunikatif dan praktis. Qawaid/grammar yang tidak praktis dan tidak komunikatif dalam pembelajaran bahasa Arab telah gagal membentuk pembelajar terampil berbahasa, bukan saja bahasa Arab tetapi juga bahasa Inggris.

\section{METODE PEMBELAJARAN}

Pendekatan pembelajaran di atas memerlukan metode pembelajaran yang tepat. Pilihan yang tepat adalah metode eklektik, yaitu metode gabungan yang mengambil aspekaspek positifnya baik dari keterampilan maupun pengetahuan bahasa, sehingga mencapai tujuaan dan hasil pembelajaran yang maksimal. Metode eklektif dimaksud mencakup metode percakapan,membaca, latihan, dan tugas.

\section{RANCANGAN MATERI AJAR DAN DESAINNYA}

1. Materi Ajar Bahasa Arab

Jika kita amati suatu materi ajar bahasa terdiri atas (1) topik materi ajar dan (2) desainnya yang menggambarkan kegiatan pembelajarannya. Topik materi ajar bahasa Arab yang efektif adalah topik-topik yang komunikatif dan kontekstual tentang tema keseharian, keagamaan, iptek, dan keprodian.

2. Desainya pembelajarannya mencakup :

(1) Keterampilan Mendengar dan Berbicara (Istima'-Kalam (2) Keterampilan Membaca dan Menulis (Qira'ah-Kitabah)

3. Pelaksanaan Pembelajaran

Untuk mencapai hasil belajar bahasa Arab yang efektif dan maksimal, lembagalembaga pendidikan harus melakukan dua kegiatan, (1) pembelajaran, learning, dan (2) pemerolehan bahasa, langguage acquisition. Pembelajaran membentuk keterampilan berbahasa secara formal, sedangkan pemerolehan membentuk pemakaian bahasa secara non formal. Kedua cara ini menuntut pengajar dan 
petugas untuk mempersiapkan rencana pembelajaran (RP) yang bermutu, yaitu pembelajaran yang terukur dan terkontrol serta adanya komitmen dari semua komponen terkait. Minat dan motivasi pelajar/mahasiswa akan tumbuh jika materi ajar didesain dengan baik dan tenaga pengajarnya profesional. Tenaga pengajar tidak boleh mengajar sebelum ada pembelakalan yang diinginkan oleh komitmen lembaga. Sebab keterampilan mahasiswa dalam berba-hasa dan berpengetahuan bahasa berhubungan dengan keterampilan tenaga pengajarnya.

Cara seperti inilah yang dilakukan oleh lembaga-lembaga pengajaran bahasa yang ingin membentuk outcome-nya bermutu dan mempunyai ciri yang tampil beda dari yang lainnya.

\section{KESIMPULAN}

Berdasarkan paparan di atas dapat disimpulkan sebagai berikut :

1. Urgensi bahasa Arab dapat dilihat dari fungsi dan peranan bahasa Arab bagi kebutuhan masyarakat, karena bahasa Arab telah menjadi bahasa komunikasi internasional, bahasa agama Islam, bahasa ekonomi dan perbangkan syari'ah,bahasa kebudayaan, iptek, dsb.

2. Untuk menjadi pembelajar, ustadz, calon ulama yang bermutu sangat diperlukan pemahaman dan penguasaan bahasa Arab.Jika tidak, ia akan mengalami kesulitan untuk membangun dirinya dalam kajian-kajian ilmu keagamaan Islam, dsb.

3. Pelaksanaan pembelaaran yang efektif memerlukan adanya seleksi terhadap materi ajar dan desain pembelajaran yang tepat, sebagaimana penulis jelaskan di atas.

\section{DAFTAR PUSTAKA}

Bisri, M. dan Abdul, H. (2012). Metode dan Strategi Pembelajaran Bahasa Arab. Malang: UIN Maliki Press.

Abdul Hamid, dkk. (2012). Pembelajaran Bahasa Arab, Pendekatan, Metode, Strategi, Materi, dan Media, Malang: UIN-Malang Press.

Arsyad, A. (2010). Bahasa Arab dan Metode Pengajarannya. Yogyakarta: Pustaka Pelajar.

Amin Muhammad. (1980). al-Lughat al-‘Arabiyyah Ma'nâhâ wa Mabnâhâ. Mesir: Dâr elFikr. 
Ismail, \& Haryati S, Nas. (2008). Studi Bahasa Arab dan Kata Serapan Bahasa Arab dalam bahasa Indonesia. Semarang: RUMAH INDONESIA

Intan. S.D. (2016). Bahasa arab dan urgensinya dalam Memahami al-qur'an. Jurnal Dakwah AlHikmah, 40-49.

Izzan, A. (2007). Metodologi pembelajaran bahasa Arab. Bandung: Humaniora. 